International Journal of Agriculture and Environmental Research

ISSN: 2455-6939

Volume: 07, Issue: 06 "November-December 2021"

\title{
ORGANOMINERAL EFFECT ON THE INITIAL DEVELOPMENT OF CORN
}

\author{
${ }^{1 *}$ Marcos Miguel Pinaffi Scanavach, ${ }^{2}$ Kleso Silva Franco Junior, ${ }^{3}$ Giselle Prado Brigante \\ ${ }^{1}$ Department of Fitotecnia, CESEP Machado MG, Brazil.
}

ORCiD: 0000-0002-6803-2768

${ }^{2}$ Department of Fitotecnia, CESEP Machado MG, Brazil.

ORCiD: ORCiD 0000-0002-6807-8889

${ }^{3}$ Department of Fitotecnia, CESEP Machado MG, Brazil.

ORCiD: ORCiD 0000-0002-0952-0075

*Corresponding Author

DOI: https://doi.org/10.51193/IJAER.2021.7606

Received: 26 Nov. 2021 / Accepted: 03 Dec. 2021 / Published: 04 Dec. 2021

\begin{abstract}
As the population increases, the demand for food is intensified, a production of food of animal origin, especially dairy production in an intensive system, can result in environmental problems. Such production results in the accumulation of waste that, if not managed, can cause environmental contamination. Allied to this stabled production, there is a need to supply food via trough, where one of the main types are bulky ones, with corn silage as a traditionalism in this category. The Compost Barn System, in which the animals are on the bed of organic material and the feces and urine of these animals, together with the action of microorganisms, compost this bed, stabilizing the manure, which can be used as fertilizer. it was held from September 2021 to November 2021, at Sitio Pinheirinho, located in Bairro Pinhalzinho in the city of Machado Sul de Minas Gerais, where it was conducted in 101 plastic bags where it was sown as corn seeds. The experiment was installed in a randomized block design - DBC, with 6 treatments in 4 replications, totaling 24 plots. Where it had as comments the height of the plant, diameter of the calm, fresh and green mass. It can be observed with the following work that when the organic compost coming from the Compost Celeiro is manufactured in the amount required by the corn crop, there is good initial development in relation to the green and dry mass.
\end{abstract}


International Journal of Agriculture and Environmental Research

ISSN: 2455-6939

Volume: 07, Issue: 06 "November-December 2021"

Keywords: Final manuscript, Guidelines, Instructions, Prospective authors, Template

\section{INTRODUCTION}

Brazilian livestock is exploited in extensive, semi-extensive and intensive systems, and the intensification of the systems makes it necessary to supply food via food and silage, thus, the demand for corn is significant, leading to the need of the rancher to cultivate or acquire this product. These intensive systems, are major adherents of technologies. Whether in relation to food or structure, being in this aspect of structure, the use of Compost Barn, which provides a greater number of animals per $\mathrm{m}^{2}$ with environmental comfort and improvement in the health of animals.

This system is a technology that comes from the USA, which has gradually been introduced in Brazilian properties, especially in large enterprises.

This system is a technology that comes from the USA, which has gradually been introduced in Brazilian properties, especially in large enterprises. Herds, whether dairy or cutting, in intensification systems, end up concentrating the production of waste, which can become an environmental polluting agent. In this sense, Compost Barn, by keeping the animals tabulated on the bed of organic material, where the feces and urine of the animals, are being absorbed by this bed, and action of microorganisms, is promoting the decomposition of these materials, where after a certain time, this bed is decomposed / stabilized and can be used as organic compound in agriculture

The composition of this bed can be varied, depending on the material used as a base, which may be coffee straw, shavings, sawdust, etc. These compounds can be enriched with chemical fertilizers, forming organomineral fertilizers. According to the regulations on: organic fertilizers and biofertilizers. (IN $61-08 / 072020$ ) [3]

Among the fertilizers that can be introduced in this compound, we highlight the rock powders that are ground rocks in different particle sizes, to result in a gradual release of nutrients, such as; Potassium, Calcium, Iron, Magnesium, Sulfur and Silicon, depending on the rock that will be extracted. This product is usually offered at a very low value of chemical fertilizers, because they have low solubility.

The use of this type of fertilizer has been increasingly the adoption of c because it provides benefits in the availability of elements, in addition to the physical and biological contribution of the soil. Objective of this research to evaluate the effect of different organominerals on the initial development of summer corn crop. 
International Journal of Agriculture and Environmental Research

ISSN: 2455-6939

Volume: 07, Issue: 06 "November-December 2021"

\section{MATERIAL AND METODOS}

The research was conducted from September to November 2021, at Sitio Pinheirinho, located in the Pinhalzinho neighborhood in the city of Machado Sul, Minas Gerais, located at geographic coordinates: latitude $21^{\circ} 43^{\prime} 06^{\prime \prime S u l}$ and longitude $45^{\circ} 50^{\prime} 01^{\prime \prime}$ North. The climate of the region is classified as hot and temperate, where summer presents higher rainfall when compared to winter (CLIMATE DATA, 2020) [2]. Plastic containers of 101 were used, filled with soil-based substrate, which was made the correction with the use of limestone according to the results of soil analysis and subsequently corn sowing with 7 seeds (Zea mays L) hybrid 3069 BIOMATRIX, carrier of transgenics RR (Roundup Ready) and PRO3 technology, silage production aptitude material, sowing was carried out according to the util area of the recipitente the proportion of a population of 70,000 plants/ha-1.

For weed management, a herbicide based on potassium glyphosate-salt $620 \mathrm{~g} \mathrm{~L}-1$ was carried out with a dosage of $2.5 \mathrm{~L}$ ha-1 with a syrup volume of $200 \mathrm{~L}$ ha-1 applied at the V4 stage of corn. For maize diseases and pests, the herbicide was also applied to the herbicide (epoxiconazole $50 \mathrm{~g}$ L-1 and pyraclostrobin 133g L-1) at the dosage of 500ml ha- 1 and the insecticide based on (thiamethoxam 141g L-1 and lambda-cyalothrin 106g L-1 at the dosage of 300ml ha-1.

The experiment was installed in a randomized block design - DBC, with 6 treatments and 4 replications, totalling 24 plots. The treatments will be arranged as shown in Table 1.

Table 1: Treatments

\begin{tabular}{|c|c|c|c|c|}
\hline Treatments & $\begin{array}{c}\text { Cultur } \\
\mathrm{e}\end{array}$ & Components & $\begin{array}{l}\text { Composition } \\
\text { NPK }\end{array}$ & Observation \\
\hline T1 & Corn & - & - & Witness \\
\hline $\mathrm{T} 2$ & Corn & $\begin{array}{c}\text { organic compost + } \\
08-28-16\end{array}$ & $\begin{array}{l}4 \text { ton ha-1 } \\
\text { organic compost } \\
+375 \mathrm{~kg} \mathrm{ha}-1 \\
\text { from } 08-28-16\end{array}$ & $\begin{array}{c}\text { Organic } \\
\text { compound }+ \\
\text { formulated NPK }\end{array}$ \\
\hline T3 & Corn & Organic Compound & $\begin{array}{l}7 \text { ton ha- } \\
{ }^{1} \text { Organic } \\
\text { Compound. }\end{array}$ & $\begin{array}{c}\text { Organic } \\
\text { Compound }\end{array}$ \\
\hline $\mathrm{T} 4$ & Corn & $\begin{array}{c}\text { Organic Compound + } \\
\text { Ammonium Sulfate }+ \\
\text { Kamafugite }+ \\
\text { Simple Super Phosphate. }\end{array}$ & $\begin{array}{c}4 \text { ton ha- } 1 \text { of } \\
\text { organic compost } \\
+50 \mathrm{~kg} \text { ha- } 1 \text { of } \\
\text { ammonium } \\
\text { sulfate }+930 \mathrm{~kg}\end{array}$ & Kamafugite \\
\hline
\end{tabular}


International Journal of Agriculture and Environmental Research

ISSN: 2455-6939

Volume: 07, Issue: 06 "November-December 2021"

\begin{tabular}{|c|c|c|c|c|}
\hline & & & $\begin{array}{c}\text { ha-1 of } \\
\text { kamafugite } \\
+117 \mathrm{~kg} \text { ha- } 1 \text { of } \\
\text { super simple } \\
\text { phosphate. }\end{array}$ & \\
\hline T5 & Corn & $\begin{array}{c}\text { Organic compound + Verdete } \\
+ \\
\text { Simple Super Phosphate + } \\
\text { Ammonium Sulphate. }\end{array}$ & $\begin{array}{c}4 \text { ton ha- } 1 \text { of } \\
\text { compost }+280 \mathrm{~kg} \\
\text { ha- } 1 \text { of verdigris } \\
+275 \mathrm{~kg} \text { ha- } 1 \text { of } \\
\text { super simple }+50 \\
\text { kg ha- } 1 \text { of } \\
\text { ammonium } \\
\text { sulfate. Verdigris }\end{array}$ & Verdigris \\
\hline T6 & Corn & $\begin{array}{l}\text { organic compound + Super } \\
\text { Simple Phosphate }+\mathrm{KCl}+ \\
\text { Ammonium sulfate. }\end{array}$ & $\begin{array}{c}4 \text { ton ha-1 of } \\
\text { organic compost } \\
+275 \mathrm{~kg} \mathrm{ha}-1 \text { of } \\
\text { super simple }+51 \\
\mathrm{~kg} \text { ha- } 1 \text { of } \mathrm{KCl}+ \\
50 \mathrm{~kg} \text { ha- } 1 \text { of } \\
\text { ammonium } \\
\text { sulfate. simple } \\
\text { fertilizers }\end{array}$ & simple fertilizers \\
\hline
\end{tabular}

Recommendations based on productive potential, according to Ribeiro et al. (1999) [6], where all treatments will receive the same concentration of $\mathrm{N}, \mathrm{P}$ and $\mathrm{K}$ at planting.

Covering fertilizer, $333 \mathrm{~kg}$ ha-1 of 300018 (conventional fertilizer) was applied 20 days after planting in all repetitions.

After 56 days of emergence, stem diameter at ground level $(\mathrm{cm})$, plant height $(\mathrm{m})$ was evaluated according to AZEEM et al [1]. (2021) and Fresh and dry mass weight (kg ha-1) according to Oliveira et al. (2015). [7]

The results obtained from the evaluated characteristics were subjected to analysis of variance using the Sisvar® software (Ferreira, 2014) [5], using the F Scoot Knott test at 5\% probability.

\section{RESULTS AND DISCUSSION}

61 days after maize emergence, stalk diameter, height, average weight of green mass and shoot dry mass of plants were evaluated, according to the data in table 2 . The organic compost was the 
treatment that presented the best result, differing statistically from the others, Santos et al. (2020) [8] presents similar results in grasses where the use of organic compost promoted statistical results of volume superior to other treatments. Vania et al. (2019) [10] in their research, highlights that the use of fresh or tanned litter resulted in greater plant height, a desirable factor for silage production, when compared to plots that did not receive application of organic material, they still report that there were positive results from the compost organic in raising the nutrient contents in the soil, mainly where the silage was done.

Table 2: Green mass weight in kg ha-1 and Dry mass weight kg ha-1, Stalk diameter at ground level $(\mathrm{cm})$ and plant height $(\mathrm{m})$, evaluated 61 days after planting

\begin{tabular}{|c|c|c|c|c|}
\hline Treatments & $\begin{array}{c}\text { Green Mass (Kg } \\
\left.\mathrm{ha}^{-1}\right)\end{array}$ & $\begin{array}{c}\text { Dry Mass (Kg } \\
\left.\mathrm{ha}^{-1}\right)\end{array}$ & Height (m) & Diameter $(\mathrm{cm})$ \\
\hline 1- Witness & $571 \mathrm{C}$ & $118 \mathrm{~B}$ & $0,49 \mathrm{D}$ & $12.65 \mathrm{~B}$ \\
\hline $\begin{array}{l}\text { 2- Organic } \\
\text { compound+ } \\
\text { formulated }\end{array}$ & $775 B$ & $123 \mathrm{~B}$ & $1,22 \mathrm{~A}$ & $20.40 \mathrm{~A}$ \\
\hline $\begin{array}{l}\text { 3- Organic } \\
\text { compound }\end{array}$ & $1487 \mathrm{~A}$ & $157 \mathrm{~A}$ & $0,73 \mathrm{C}$ & $13.32 \mathrm{~B}$ \\
\hline $\begin{array}{c}4- \\
\text { Organomineral } \\
\text { with Kamafugito }\end{array}$ & $647 \mathrm{C}$ & $95 \mathrm{~B}$ & $0,70 \mathrm{C}$ & 14.15 B \\
\hline $\begin{array}{l}\text { 5- } \\
\text { Organomineral } \\
\text { with Verdete }\end{array}$ & 1112B & 119B & $0,72 \mathrm{C}$ & $14.80 \mathrm{~B}$ \\
\hline 6- Organomireral & $364 \mathrm{C}$ & 84B & $0,88 \mathrm{~B}$ & $15.45 \mathrm{~B}$ \\
\hline $\mathrm{CV} \%$ & 28,43 & 21,59 & 9.92 & 10.68 \\
\hline
\end{tabular}

*Media followed by different letters in the column differ statistically by the $5 \%$ probability Knoot scoot test

For the plant height parameter, the results show that the use of organic compound + formulated fertilizer 08-28-16 + Zn (organomineral), used in planting resulted in the highest plant height, differing statistically from the other treatments. To strengthen this research, VIEIRA et al. (2020) [11], evaluated cabbage and lettuce fast-cycle plants and achieved a productivity increase of $11 \%$ with the use of organomineral compared to $100 \%$ mineral fertilization. Possibly the organic fraction was made a protection to the chemical material, thus reducing losses by adsorption, leaching and volatilization, allowing the plant to make better use of the fertilizer's nutrient. 
International Journal of Agriculture and Environmental Research

ISSN: 2455-6939

Volume: 07, Issue: 06 "November-December 2021"

In relation to stem diameter and height at ground level, the organic compost $+08-28-16+\mathrm{Zn}$ (organomineral) formulated fertilizer was statistically superior to the others, Silva et al. (2020) [9] stated in their work, where the soybean crop with fertilizer supply via pelleted organomineral resulted in increased crop production. The research carried out by Faria et al. (2020) [4], with Heliconia psittarum $x$ Hiliconia pathocircinada, with organic mineral fertilization, increased production and accelerated the cycle, advancing flowering and subsequent harvest in relation to plots with only organic fertilization. Possibly the treatments with organomineral showed better statistical results in the parameters of calm diameter and height at ground level due to having in its composition organic and mineral material, where the mineral is already available for the plant while the organic one needs to be mineralized so that it can be found in available forms there is plant. When only the organic source is found, it is dependent on this mineralization, which can take a long time to be offered to the plant, especially plants that need the nutrient right at the beginning of their cycle, such as corn.

The organic compost produced with Compost Barn bedding is already stabilized manure, due to the process it undergoes during the time it is submitted as stable bedding for the animals, thus having a daily turnaround providing oxygen for organisms to decompose all the matter there. present thus leaving stabilized over time.

As the treatments with rock dust did not stand out statistically in the work evaluated, it can be observed that the nutrients present there are possibly not readily available to corn at the beginning of its cycle.

\section{CONCLUSION}

It is concluded that the use of organic compost from the production of compost barn beds, used in accordance with the recommendation for fertilization of the corn crop, where the amount of compost based on its nutrient content and the demand of the crop was applied, provided a good initial development of the crop in relation to green and dry matter.

\section{REFERENCES}

[1] AZEEM, K.; NAZ, F.; JALAL, A.; GALINDO, F. S.; TEIXEIRA FILHO. M. C. M.; KHALIL, F. Aplicação de doses de ácido húmico e nitrogênio na cultura do milho em solo alcalino. Rev. bras. eng. agríc. Ambiente, 09 mai 2021. Disponível em:<https://doi.org/10.1590/1807-1929/agriambi.v25n10p657-663>. Acesso em 13 de setembro de 2021

[2] CLIMA-DATA.ORG. Machado Clima Brasil. Disponível em<https://pt.climatedata.org/america-do-sul/brasil/minas-gerais/machado-24990/>. Acesso em 05 maio 2021 
International Journal of Agriculture and Environmental Research

ISSN: 2455-6939

Volume: 07, Issue: 06 "November-December 2021"

[3] INSTRUÇÃO NORMATIVA N ${ }^{\circ}$ 61, DE 8 DE JULHO DE 2020.DIÁRIO OFICIAL DA UNIÃO. Órgão: Ministério da Agricultura, Pecuária e Abastecimento/Secretaria de Defesa Agropecuária. Publicado em: 15/07/2020 | Edição: 134 | Seção: 1 | Página: 5.Disponível em: https://www.in.gov.br/web/dou/-/instrucao-normativa-n-61de-8-de-julho-de-2020-266802148. Acesso em 20 set 2021

[4] FARIAS, A.P.; ALBULQUERQUE, A. W.; MOURA FILHO. G.; REIS, L. S. Adubação fosfatada organomineral em milheto em solo arenoso, Revista Brasileira de Engenharia Agrícola e Ambiental. OUTUBRO DE 2020. Disponivel em:<https://doi.org/10.1590/1807-1929/agriambi.v24n10p694-699>. Acesso em:27 nov 21.

[5] FERREIRA, D. F. Sisvar: um guia dos seus procedimentos de comparações múltiplas Bootstrap. Ciência e Agrotecnologia. Lavras, v.38, n. 2, p. 109-112, mar/abr. 2014. Disponível em: <https://www.scielo.br/scielo.php?script=sci_arttext\&pid=S141370542014000200001>. Acesso em 12out. 2021.

[6] Ribeiro, A.C.; Guimarães, P.T.G.; Alvarez, V.V.H. (Ed.). (1999) - Recomendação para o uso de corretivos e fertilizantes em Minas Gerais: 5. Aproximação. Viçosa: Comissão de Fertilidade do Solo do Estado de Minas Gerais. 359 p.

[7] OLIVEIRA, J.S.; MIRANDA,J.E.C.; CARNEIRO, J.C.D.; D'OLIVEIRA, P.S.; MAGALHAES, V.M.A. Como medir a matéria seca (MS\%) em forragem utilizando forno de micro-ondas. Juiz de Fora. Embrapa Gado de Leite. nov 2015 6p. (Embrapa Gado de Leite ISSN 1678-3131 comunicado técnico 77).

[8] SANTOS, P.L.F.; SILVA, P.S.T.; MATOS, A.M.S.; ALVES, M.L.; NASCIMENTO, M.V.L.; CASTILHO, R.M.M. Qualidade estética e sensorial da grama esmeralda (Zoysia japonica) em função do cultivo em substratos e adubação mineral. Ornamental Horticulture. (Julho de 2020). Disponível em:<https://doi.org/10.1590/2447536X.v26i3.2216>. Acesso em 26 set 2021.

[9] SILVA, L. G.; CAMARGO, R. de; LANA, R. M. Q.; DELVAUX, J. C.; FAGAN, E. B.; MACHADO, V. J. Mudanças químicas e desenvolvimento da soja com utilização de fertilizantes organominerais peletizados à base de lodo de esgoto e bolo de filtração. Acta Scientiarum Agronomy, v.42, p.1-9, 2020. Disponível em: <https://doi.org/10.4025/actasciagron.v42i1.44249>. Acesso em: 03 maio 2021.

[10] VANIA, C. M. et al. Aproveitamento da cama de confinamento de bovino para adubação orgânica do milho. Revista Brasileira de Engenharia Agrícola e Ambiental, v.23, n.8, p.620-624, 2019. Disponivel em:< https://www.scielo.br/pdvaf/rbeaa/v23n8/1415-4366rbeaa-23-08-0620.pdf> Acesso em: 4 set. 2020.

[11] VIEIRA D.M. S. et al. Cultivo de hortaliças em sucessão em diferentes solos e doses de fosforo via fertilizante organomineral. Revista Brasileira de Engenharia Agrícola e 
International Journal of Agriculture and Environmental Research

ISSN: 2455-6939

Volume: 07, Issue: 06 "November-December 2021"

Ambiental. v.24 n.12 Campina Grande, 13 de novembro de 2020. Disponivel em: $<$ https://www.scielo.br/scielo.php?script=sci_arttext\&pid=S1415-

43662020001200806>. Acesso em: 01 maio 2021. 